\title{
Privatization in an Adverse Institutional Context: The Case of Kosovo
}

Bardhyl Dobra ${ }^{1}$, Michiel $S$ de Vries $^{2}$

\section{Abstract}

Regarding the effectiveness of privatization, two schools of thought are distinguished: a school in favor of privatization in general and a school that judges the success of privatization to be dependent on the institutional context. This article discusses the arguments of both schools and presents a case study on the privatization processes that did take place in Kosovo. The Kosovo case is a critical case as Kosovo was a post-conflict country with a deplorable institutional setting at the time it initiated the privatization processes. If privatization was successful anyway, this would make for a strong argument in favor of privatization in general.

The outcomes of the case study show, however, many unintended and negative effects of privatization in the Kosovo context. The conclusion, therefore, disputes the claim that privatization is beneficial in general, irrespective of the institutional setting. Instead, the article makes a plea for creating a favorable institutional setting before starting far-reaching transformations through large-scale privatization.

The issues arising from this article are important for policy-makers and international missions considering implementing similar programs to other postconflict countries.

\section{Keywords:}

privatization, institutional framework, Kosovo, post-conflict state building.

1 Bardhyl Dobra is a PhD student at the Ghent University and Executive Secretary of the International Association of Schools and Institutes of Administration, Brussels, Belgium, email: bardhyl. dobra@ugent.be

2 Michiel S de Vries is full professor and chair of the department of Public Administration, Radboud University Nijmegen, Institute for Management Research, The Netherlands, email: m.devries@ fm.ru.nl 


\section{Introduction}

In the economic and public-administration literature, there is a debate on the merits of privatization policies (Lipton and Sachs 1990; Laffont and Tirole 1991; Stiglitz 2008; Roland 2008; Savas 2000; Bozeman 2007). On the one hand, neoliberal theorists praise privatization and its positive effects on socio-economic development in general. They suggest that although employment might first decrease, it will eventually increase after the necessary adjustments have been made by the new management. Then, privatization will attract foreign investments that in their turn will further contribute to economic and social developments and the improvement of local entrepreneurship. On the other hand, institutional and regulation schools of thought suggest that in order for this model to work, strong institutions are crucial (North 1991) and that adaptation of privatization models to the specifics of the context of the country is needed. Their idea is that only then the model can be effectively implemented.

In post-communist societies, privatization processes were conceived to be, at least at the start, the ultimate action towards growth and development, and a break from the past (Hanley and Dawson 2016). Sometimes such attempts did have the promised results, at other times they did not (cf. Dan and Pollitt 2015; Drechsler and Randma-Liiv 2015). Given the economic debate on privatization, one of the reasons for this varying success could be the starting position regarding the strength of government and the public institutions in a country.

This article assesses the effects of the privatization processes in Kosovo between 1999 and 2008. The reforms in Kosovo started in 1999 under the influence of international missions. Because of the weakness of the Kosovo Provisional Institutions of Self-Government, one of the main objectives of this international mission was to privatize all those service delivery agencies the public sector seemed unable to manage. Privatization generally involves a decrease of state participation in an enterprise or service (Wright 1993). The case of privatization in Kosovo is an extreme case, because of the extreme weakness of public institutions in this country and its starting position. Kosovo went through a war which ended in 1999 with NATO intervention and the establishment of the United Nations Mission in Kosovo (UNMIK), aiming primarily at "State building and the establishment of self-managed institutions" (Knudsen 2010).

That background enables us to use the case of Kosovo to answer the main research question of this article: What were the effects of the privatization processes in Kosovo in terms of governance, employment and social well-being in Kosovo? Alongside answering this question this paper also addresses what this answer implies for the two contesting theories about privatization. This relates to the idea that privatization is beneficial in general and also that its success depends on the existence of strong institutions. 
In order to answer the research question we first present the theories on the impact of the institutional setting on privatization. Subsequently we give an overview of the weak institutional setting in Kosovo at the start of the privatization process in 1999. Then we assess the privatization process in this fragile state, and finally we give an assessment of the effects thereof.

This case study is based on document analysis, reports of local research institutions, available data produced by institutions within Kosovo (including the Kosovo Trust Agency-KTA), by international institutions such as the International Monetary Fund (IMF), and also with the assistance of semi-structured interviews with local experts. We searched for literature on the reasons for privatization as used in Kosovo within the context of privatization processes in Central and Eastern Europe during the time of transformation in the 1990s. This allows us to understand the conception of the model used in this part of Europe. We consulted publications that analyze the privatization process in the Balkan region with a special focus on the case of Kosovo and, if possible in relation to the international administration management of the process. Additionally, we sought for opinions on privatization of representatives of the institutions involved in the process, such as the Trust Agency of Kosovo (which in 2008 became the Privatization Agency of Kosovo), the government, the UN mission, the International Monetary Fund and the World Bank. Their reports as well as local independent research contributions were reviewed. Furthermore, semi-structured interviews with actors directly or indirectly involved in the process of privatization (including representatives from the government ${ }^{3}$, the IMF, local institutes and managers of a privatized enterprise etc.) complete the picture.

The topic is not only relevant for Kosovo, but could have wider implications, since privatization is pursued by and imposed on many countries irrespective of the strength of the institutional setting. Therefore, it might be crucial to understand whether countries that lack proper institutions can successfully go through such kinds of processes or whether the implementation of such processes in such countries is likely to result in unexpected and harmful side effects.

\section{Two views on privatization}

History knows many eras in which processes of privatization, by which governmental organizations transfer tasks and responsibilities to the private sector, became popular (Nemec and de Vries 2015). The last upheaval of such practices started in the UK and USA under Thatcher and Reagan, respectively. In the UK it involved, for instance, the privatization of British Petroleum in 1979, followed in the 1980s by British Aerospace, Amersham International, the National Freight Company, Britoil, British Ports, Jaguar Cars, British Telecom and British Airways (cf. Nemec and de Vries 2015).

3 For personal safety and fear of reprisals, they have preferred to stay anonymous. 
Such privatization was the preferred policy within Neo-liberal theories, as privatization results in the disappearance of state monopolies and the creation of a large number of private competitors that compete and thus create a market based on demand and supply, which is assumed to be favorable for the population (Labaronne 2001). The idea is that such a transfer of state monopolies suffices to create an environment favorable to competition, consequently having a positive impact on consumption, employment, growth etc. Privatization is seen as a way to replace the dominance of decisions by planned economy hierarchy into a dominance of decisions made by private agents based on the incentive that being responsive to market signals results in maximizing profit (Harvylyshyn and McGettigan 1999). In this ideological point of view, the liberal dogma has been welcomed in CEE countries after the transition, as communism had shown its limitations for more than forty years (Kornai 1999). Economists leading the IMF or World Bank's missions in countries in Central and Eastern Europe brought the dogmas to these countries and tried to implement them as such. This neo-liberal view was also reflected in the theory on New Public Management, favoring a mixture of the delivery triad of privatization, contracting-out and public-private partnerships (Drechsler and Randma-Liiv 2015). However, it was not only ideology. There are also several wellknown theories supportive of privatization.

In the school of Property Rights, private management is considered to be superior to public property, because private management is driven by profit maximization and is more inclined to work on improving the effectiveness and efficiency of the enterprise. This is not the case for a public manager, as this official is not profitoriented (Bayliss 2005). Based on the work of Ronald Coase and Harold Demsetz, Starr (1988) argued that individuals tend to abuse and ultimately destroy what is public, but tend to take good care of their own private property. The idea is, for instance, that because of soft-budget constraints, the near-impossibility of public bankruptcy, the almost unconditional financial support from the State, in public enterprises, management is not inclined to make serious efforts to control the process of production and to eliminate potential waste (waste of time, raw materials etc.) (Kornai 1986).

Public-choice theorists argue that politicians and bureaucrats make decisions based on the effects thereof for their political careers (Wright 1993). Politicians and bureaucrats controlling public-service delivery will deliver excessive public services in order to satisfy particular groups of interest who will in return help them to get re-elected (Bel and Warner 2006). This theory promotes the notion that private property would help to internalize the externalities and, therefore, would better ensure the optimal allocation of resources and the effectiveness of the free market.

From a principal-agent theoretical standpoint, Jensen and Meckling (1976) argued that from the moment management and ownership are separated, an agency relation is created with a principal and an agent. This implies that the principal 
delegates decision-making to the agent. Whether this is advantageous depends, among other things, on the information asymmetry between principal and agent. Jensen and Meckling argue that the public sector is much more subject to such information asymmetry. This is the case, because the complexity of responsibilities of different ministries and public agencies creates an environment that encourages such information asymmetry with the consequence that public managers are in a better position to act in a way that is suitable for their own profit, irrespective of whether it is advantageous for the principal (politicians and public). Accordingly, it is more likely in the public sector that a manager will first seek to satisfy his/her own interest and will try to improve his/her own situation instead of acting in accordance to the interests of the principals. Jensen and Meckling judge this to be less likely in the private sector, because even if the manager hides information from shareholders, the market will eventually regulate this behavior through changing demand and falling stock prices of shares, immediately having consequences for the position of the manager.

Contrary to these "one-size-fits-all" theories promoting privatization in general, the perspective of neo-institutional theories is that privatization can be supported, but only after strong institutions have emerged. In this theory, the neo-liberal theories are criticized for their neglect thereof. Already at the time of transition in CEE countries, it was argued that such practices were doomed to fail, because they did not take into consideration that the institutional framework in CEE-countries was fragile and that these countries needed gradual reforms, strong institutions and regulators (Tirole 1991). North (1991) argued that economic performance depends ultimately on a strong institutional framework. To quote from his speech while receiving the Nobel Prize in 1993:

It is the admixture of formal rules, informal norms, and enforcement characteristics that shapes economic performance. While the rules may be changed overnight, the informal norms usually change only gradually. Since it is the norms that provide legitimacy' to a set of rules, revolutionary change is never as revolutionary as its supporter's desire and performance will be different than anticipated. And economies that adopt the formal rules of another economy will have very different performance characteristics than the first economy because of different informal norms and enforcement (North 2014, para. 42).

The implication is that transferring the formal political and economic rules of successful Western market economies to Third World and Eastern European economies is not a sufficient condition for good economic performance according to these theorists. Privatization is not a panacea for solving poor economic performance. The institutional mainstream recommends a gradual process of privatization, which, in other terms, is easily managed, controlled and, if needed, modified. 
Institutions will frame the process and ensure its effectiveness. In addition, when necessary, institutions may correct, avoid or take measures against issues such as corruption, mismanagement etc.

The 2014 Nobel Prize winner, Tirole (1991), defends the idea of creating an appropriate environment, which helps creating a free market. Indeed, he argues that it is necessary to create an environment where there is no pure monopoly, but rather competition. He argues that:

since at least Montesquieu and the American Federalists, it has been well understood that strong safeguards must be put in place to prevent governments from serving the interests of specific groups. Many of these safeguards did not exist under the previous regimes and will take time to install: organization and rotation in the civil service, administrative procedures and regulatory hearings, independent administrative courts, checks and balances in government, development of a tradition of investigative reporting by the media, etc. (Tirole 1991, 240).

While praising privatization, Tirole points out that it is crucial to have a clear timetable, with well-defined steps, and, above all, strong regulatory bodies. He also insists on tailored policy recommendations; tailored to the industrial and political realities and specifics of each country. It is for such reasons that, among others, Stiglitz (Komisar 2011) reinforces the idea that international institutions such as the IMF and the WB, instead of asking for deregulation, should help countries develop what he calls "the right regulatory structure".

Numerous prerequisites for successful privatization are mentioned in the literature. They involve good governance and strong governmental oversight through valid performance indicators. They also include principles of democratic legitimacy, transparent public accountability, a normative role of the legislative, an adequate conceptual framework, an unequivocal decision framework, uniform regulations and a single ministry to take the lead. At the operational level it is deemed necessary to have adequate steering instruments and the capacity to evaluate such processes, weighing public interests against individual interests, arranging accountability, as well as possibilities for citizens to make complaints (cf. Nemec and de Vries 2015).

The above makes it clear that contesting views exist regarding the general benefits of privatization and the dependence of its success on contextual features.

\section{Privatization in Kosovo}

This section describes the privatization processes that occurred in Kosovo between 1999 and 2009. First, we present the context in which these processes took place. This will show that Kosovo lacked an adequate institutional setting. This part of the 
analysis argues that the case of Kosovo is a critical case. If privatization processes work out even under the circumstances as witnessed in Kosovo, this would be a strong argument in favor of theories promoting privatization in general.

Next, we present the actual privatization processes that took place in Kosovo, and in the third subsection we assess the effects thereof. The outcomes will constitute the empirical basis for the argumentation whether the claim made by theorists being in favor of privatization in general is indeed valid.

\subsection{The context}

The Balkan region is well-known for its complex history, which has always been characterized by hostile relations between and within the countries involved. A brief historical background of this context is needed in order to understand the privatization processes in this region.

In 1945, the Socialist Federal Republic of Yugoslavia (SFRY), under the commandment of Tito, was a socialist country. From the 1960s onwards, a process started to grant larger autonomy to Kosovo and Vojvodina within the Federation, which was also explicitly stated in the Constitution of 1974. Pavlovic (2013) describes the changes that the constitution brought to the situation of Kosovo within SFRY:

The process of reorganizing the Yugoslav federation, which started in the late 1960s, reached its climax in the 1974 constitution. For the first time, republics and even the autonomous provinces of Vojvodina and Kosovo had their own constitutions. ... According to the constitution, the Assembly of Socialist Autonomous Province of Kosovo had the power to change the constitution of SAP Kosovo, had a vote in the event of changes to the federal constitution or to the constitution of Serbia, and had the power to decide on other crucial questions regarding the political, social, and cultural development of the region. It also had the power to issue laws and budgets, to appoint and recall the president and the members of the executive council of the SAP Kosovo Assembly, the judges of the Constitutional Court of Kosovo, the judges of the Supreme Court of Kosovo, secretaries of the region, and other officials in Kosovo institutions. It controlled the executive council and other administration bodies of the province (Pavlovic 2013, para. 1 and 3).

The new constitution not only brought about an important advancement in terms of democracy, it also contributed to softening the economic policy and gave more liberty to local entrepreneurship and to the employees of the until then public enterprises by creating so-called "socially-owned enterprises" (Garde 2000; Brossard and Vidal 2001). 
The "socially-owned enterprises" regrouped different branch enterprises and public services: agricultural cooperatives, veterinary clinics, municipal public transports, industrial enterprises etc. and were steered by a Directorate General and the "workers' council". Theoretically, the latter had the capacity to veto the decisions of the Directorate General. Specialized entities of the enterprise fixed the objectives of the organization and were sent for approval to the Workers' Council. However, the real ownership remained "undefined and unidentifiable" within the Yugoslavian legislation (Knudsen 2010).

With the "announced" fall of communism, Slobodan Milosevic took over the leadership of the Communist Party in Serbia, concentrated power and annulled the previously granted autonomy of Kosovo. On 28 March 1989, he was able to abolish Kosovo's autonomy completely. In parallel with the changes of the political spectrum in Yugoslavia, Milosevic also changed the economic policies (Castellan 1994; Brossard and Vidal 2001). With so-called compulsory/emergency measures (the decree of 23 March 1989), three policies were introduced: 1) the firing of the majority of Albanian public servants and workers of the Socially Owned and Public Enterprises, 2) the transformation of all socially-owned enterprises into public enterprises administered by his loyalists sent from Belgrade, 3) transference of property rights of SOEs in Kosovo to Serbian public enterprises (Malcolm 1998).

The case of Trepça - the largest mining complex of ex-Yugoslavia - illustrates the situation. After having fired all Albanian managers and the majority of Albanian employees, Milosevic appointed his loyalists as directors of the company and replaced the Albanian workers with workers from Serbia and Serbs from Bosnia (leaving the country because of the war). Afterwards, the regime transformed the company into a shareholding company controlled by public enterprises from Serbia.

The prospects for Trepça worsened when the United Nations put an embargo on Serbia for its implication in the Bosnian war. During the 1990s, the Serbian administration and public enterprises started privatizing several enterprises. However, with the deterioration of the Balkan conflict into a full-fledged war, this process was abandoned. One of the consequences was that the unfinished process created additional ambiguity about property rights and ownership of enterprises in Kosovo. This is also seen in the case of Trepça, where the government was unable to privatize the enterprise for political reasons, but also because of "complaints from investors who claim to have bought the company during the era of Milosevic" (Knudsen 2010).

After Kosovo had gone through a decade of violence and a war, the situation stabilized in 1999 with the intervention of NATO and the establishment of a UN mission having as a specific assignment "peacebuilding and state-building" in Kosovo. The country was devastated, institutions destroyed, the archives taken to Serbia and chaos and disorder reigning all over. The main goal of the UN mission was to remedy these issues. 
A Special Representative of the UN Secretary-General (SRSG) became de facto and de jure the highest authority in the country. The UN mission, under the leadership of the SRSG, took control of local governments, courts and national institutions. In parallel, it created provisional institutions of self-government that were, however, in practice hardly self-governed, since each decision had to be approved by the UNMIK representatives at their different levels. In the aftermath of the war, as of 1999, newly created institutions lacked qualified personnel and infrastructure, despite the fact that Kosovars had built parallel institutions without having highly qualified human resources and adequate infrastructure (schools, universities held their courses in private houses etc.) and international missions brought assistance in capacity building, especially in fields that needed technical skills. The situation proved to be especially complicated in areas requiring highly educated personnel. Also, the judiciary system, the police, the customs, local-government institutions and national agencies needed to be restructured or newly created.

The SRSG and the UN team decided that such state-building could only be successful if it went hand in hand with economic development in which privatization had to be the core policy. As Knudsen (2010) noted:

Economic reconstruction and development, the responsibility of the EU-led pillar in Kosovo, was a daunting task at the start of the international state-building project. ... International officials quickly made it clear that large-scale privatization of Kosovo's enterprises would be the main economic strategy of the statebuilding operation (Knudsen 2010, 12).

Table 1

Administrative and institutional situation before prerequisites A comparative view on CEE countries and Kosovo

\begin{tabular}{|l|l|}
\hline \multicolumn{1}{|c|}{ CEE countries } & \multicolumn{1}{c|}{ Kosovo } \\
\hline Relatively strong central and local & Provisional institutions for self-governance \\
institutions & Weak education - exclusive during the \\
Relatively strong education system - & 1990 s \\
inclusive & Weak judicial system in need for \\
Relatively strong judicial system (courts, & reconstruction \\
contracts) & Newly created institutions in police, \\
Strong police and customs services & customs, statistics, and tax administration \\
An administrative culture (although & Lack of administrative culture \\
bureaucratic) & Ten years of isolation had destroyed trust in \\
A clear perspective to join NATO and the EU & government \\
Remaining dominance of national & Government was taken over by the \\
government & international mission \\
\hline
\end{tabular}

An overview of what was present in those other CEE countries, but absent or in some cases newly created, in Kosovo is summarized below in Table 1. The table shows that basic institutions were not present in Kosovo. Most important was that 
the legal framework was not yet finalized in 1999. In a report published in 2008, the OSCE pointed out difficult legislative issues with regard to the functioning of KTA, to the Special Chamber and the legislation that was used in the process of privatization.

We will assess the public-sector reforms and more specifically the privatization against this complex contextual background.

\subsection{The process of privatization in Kosovo}

How did the process of privatization in Kosovo start and how was it conducted by the UN administration and others institutions in charge? After the Balkan war ended, international institutions such as the World Bank, the IMF, USAID, the European Commission and the United Nations Mission in Kosovo (UNMIK) published several reports and organized numerous conferences in which the process of privatization was argued to be only beneficial for Kosovo. In 2001, the World Bank emphasized the importance of reinforcing the private sector and liberalizing the economy by urging for "the adoption of clear governance policies as well as policies facilitating the transition to a private market based economy" (World Bank 2001a, 2). In another report, the World Bank (2001b) took a clear position in favor of privatization and encouraged the UNMIK to proceed as soon as possible with the creation of necessary institutions.

Next to the more general arguments in favor of privatization, as already mentioned above, specific arguments for Kosovo were also given. First of all, there were the financial incentives of privatization, namely, providing the State with the much needed revenues, bringing in foreign currency by attracting Foreign Direct Investments and putting an end to the expensive subsidies to public enterprises. Secondly, there were economic arguments pointing to the need to improve economic effectiveness and to maximize the profit of enterprises and to facilitate macro-economic stability. Thirdly, there were arguments pointing out that privatization would restore property to former owners, privilege company employees, distribute state property to the entire population, reduce the power and pressure of unions and elaborate a kind of new social contract. Fourthly, there were political arguments, saying that privatization would push out the hated "nomenklatura", would minimize the influence of the State and would consolidate democracy by introducing popular (mass) shareholding. Last but not least, the arguments in favor of privatization were also ideological, namely to create an irreversible situation in favor of free markets and to demonstrate "the superiority" of private property (cf. Labaronne 1999).

It is therefore not surprising that already in 1999, the European Commission, together with the World Bank, stimulated the UNMIK to proceed with privatization (European Commission and the World Bank 1999). Most arguments used consisted of pointing out that the socially owned enterprises were in bad shape and needed 
investments which could only be provided by private owners (i.e. FDIs, employment and social welfare).

Notwithstanding all this pressure to proceed with privatization, the process did encounter several issues. The first problem was how to deal with the complicated issue of liability and undefined ownership over the Socially Owned Enterprises (SOEs) and land properties. Because of Serbian claims of ownership over all Kosovo assets, at first several investigations were conducted, mainly in order to find a way to proceed with mass privatization without getting in a liability contest situation and without being "suable". In respect of this point, Knudsen (2010) argues that:

Belgrade's insistence on ownership of all publicly and socially owned property in Kosovo increased the nervousness among the international officials as to future problems, should they be found to have exceeded their mandate when privatizing. ... Legal concerns, however, troubled the international state builders, particularly the undefined issue of who owned Kosovo's enterprises, and how international officials could avoid liability when privatizing them (Knudsen 2010, p. 38).

Upon the request of UNMIK, the IMF and other international institutions assisted the mission in the process of institution-building and economic policy implementation (Demekas et al. 2002). The IMF considered that compared to the status quo at the time, any other solution was better than the status quo. Hence, it supported the decision to continue with privatization, although being aware of the legal issues implied by the process (A. Domi, personal communication, 11 February 2010; Economists of Government, personal communication, 8 February 2010).

In all cases, the Special Representative of the Secretary General (SRSG) started planning privatization by combining several models of privatization that had also been used in other CEE countries, notwithstanding the differences between the starting position of Kosovo compared to those CEE countries. As mentioned above, institutions, such as administrative courts, regulatory bodies, an administrative culture etc., able to steer the transformation were present in other CEE countries, but not so in Kosovo.

Nonetheless, the authority of the SRSG, combined with the influence of Western embassies and other international missions (IMF, WB, EU mission etc.), were "rock-solid" in their decision to impose the model of privatization in Kosovo (Knudsen 2010; Musliu, personal communication, 4 April 2015).

In June 2002, the part of UNMIK in charge of Reconstruction and Economic Development, managed by the European Union (EU), launched the creation of the Kosovo Trust Agency (KTA) (UNMIK regulation 2002/12). The "creators" of KTA describe it as follows: 
The KTA has been established to preserve or enhance the value, viability, and corporate governance of socially owned and public enterprises in Kosovo. For Socially Owned Enterprises the KTA initiates 'Spin-offs' and Liquidation, its preferred procedures for privatization. The Regulations establishing the KTA were promulgated on $13^{\text {th }}$ June 2002 (http://kta-kosovo.org/html/index. php).

In addition, from June 2002 to May 2003, the mission and the self-governed institutions approved other regulations and basic legislation to proceed with privatization, including the creation of a Special Chamber which had, among others, the exclusive jurisdiction for all suits against the Agency (KTA n.d.). It created a Board of directors to manage KTA, which was composed of four international directors (one of them being the Managing Director of the Agency and three Deputy SRSG) and four Kosovars (three ministers and the President of Trade Unions) (UNMIK Regulation 2002/12; Knudsen 2010). The daily work was done by a mixed team of internationals and local experts.

On 15 May 2003, KTA decided to start the privatization of socially-owned enterprises. At the time, the Board of Directors decided to proceed with full privatization and did not follow the examples of other countries where the enterprises were sold by shares, i.e. individuals could buy shares of an enterprise $\mathrm{x}$ or $\mathrm{y}$. In Kosovo, the KTA decided to sell complete firms by tender. Although three specific methods were used - Regular Spin-off (the highest bid) (KTA, n.d.), Special Spin-off (privatization with specific conditions, mainly in the field of operation, investment and employment) and Liquidation, the idea in all three models is similar, namely to have a complete transfer of the ownership of enterprises to one new owner.

As for the profits of these privatizations and the question how these should be divided, the agency decided that "the closest" owners of these organizations were the former employees. Hence, it was decided that $20 \%$ of the revenues of the privatized organization would go to these former workers. Taking the complexity of property rights into consideration, the Agency published open calls for claims for each enterprise that was going through the process of privatization.

In Table 2, it is seen that seven organizations were to be sold, on which the agency received 17 bids, however at prices that barely reached half of the real value of the companies. The seven companies include companies that produced compartments for energy production, heating systems, engineering and construction, limestone extraction etc. The table also shows that the difference between the value of the company and the money involved in the transfer is unrelated to the number of acceptable bids. The company with the most bids (Energo Invest) had five bids, but was privatized at a price of less than one-third of its value, while Termosistem had only one interested party, but was sold at the price of its real value. 
Table 2

The first wave of privatization

\begin{tabular}{|c|c|c|c|}
\hline New Cos & $\begin{array}{l}\text { Acceptable } \\
\text { bids }\end{array}$ & $\begin{array}{l}\text { Value of the } \\
\text { company (in } \\
1,000 \text { s of } C \text { ) }\end{array}$ & $\begin{array}{c}\text { Value of the accepted } \\
\text { offer company (in } \\
1,000 \text { s of } C \text { ) }\end{array}$ \\
\hline Energo Invest (Assembly) & 5 & 2,354 & 750 \\
\hline Energo Invest (Fuses) & 4 & 1,866 & 525 \\
\hline Lepenci & 3 & 650 & 650 \\
\hline Montage Kosovo & 3 & 600 & 210 \\
\hline Përparimi & 3 & 3,573 & 2,298 \\
\hline Termosistem & 1 & 200 & 200 \\
\hline Ringov & $\mathbf{0}$ & - & - \\
\hline Total & 17 & 9,245 & 4,634 \\
\hline
\end{tabular}

Source: Mustafa et al. 2008

Socially owned enterprises (SOE) were privatized in a regrouped manner, i.e. in what the KTA called "a wave". Hence, each wave regrouped a certain number of SOEs, the latter being regrouped not in function of the branch of activity, but in function of their ability to be sold, in function of internal logic and operational modes of the KTA. According to Dobruna (2007), in the first 22 waves of privatization, a total amount of 332 million Euros was involved. Out of this, local investors invested $139 \mathrm{M} €(42 \%)$, followed by international investors for an amount of $80 \mathrm{M} €$, financial institutions (Western bank branches in Kosovo) for $78 \mathrm{M} €$ and finally the Kosovar diaspora living in Western Europe and the United States, who invested 34 $\mathrm{M} €(10 \%)$. Around $76 \mathrm{M} €$ was distributed to former employees, and the remainder of the revenues was placed at the Central Bank of Kosovo, which, under the leadership of UNMIK administrators, decided to place the privatization funds at European banks (Gerxhaliu, personal communication, 12 February 2010). Between 2003 and 2014, it is estimated that privatization in Kosovo has generated a total revenue of $660 \mathrm{M} €$ (PAK 2015).

From its beginning, the process was several times interrupted because of questions regarding the legal framework, issues of political decisions etc. As explained earlier, the issue of whether documents issued during the 1990s by the regime of Milosevic could be seen as valid forced the KTA to stop the process several times as external parties sued the KTA for having privatized their properties and not having considered such documentation. Despite these interruptions, KTA continued the waves of privatization until its transformation into the Privatization Agency of Kosovo in 2008 (PAK 2009). Sometimes the process failed, as was the case with the Post and Telecom of Kosovo (PTK). Opposition in parliament blocked this privatization, as it judged the PTK value to be under-evaluated by the bidder and the government, because of its potential for corruption, and because they feared the 
deal would have negative impacts on the economy and the employment. The case is now subject to international arbitration (TopChannel 2015).

Although the PTK case suggests that the privatization was well thoughtthrough, in all cases suspicious deals were sealed with "important organizations for the country" having been sold for symbolic amounts. Ferronikel, a giant producer of nickel, was sold for a minimal sum of 32 million euros; and the electricity distribution network for only 26 million euros, whereas comparable networks were sold in Montenegro, in Macedonia and Albania for several hundreds of millions. Thousands of hectares of agricultural land were privatized and transformed into real estate below their real value.

Ferronikel went through a special spin-off privatization, i.e. with specific employment and investment conditions. However, in order to seal this privatization, the buyer negotiated a fixed price for electricity, which covers half of the production cost (Knudsen 2010). This implies that this contract severely damages the profitability of the Kosovo Energy Corporation (KEK), a State-Owned company managed by KTA, as Ferronikel consumes around $10 \%$ of the electricity of the country (Knudsen 2010).

Financial issues are not the only ones at stake. Ferronikel produces nickel. The production thereof requires the filtering of evaporating rests, because they may be toxic and even very carcinogenic (KFOS 2012). However, Ferronikel produced nickel for several years without using filters and because proper judicial institutions are lacking, environmental and health issues have become a serious challenge for the population. Cancer has exploded in Kosovo and particularly in the areas near the Ferronikel production site.

Notwithstanding these issues, the UN administration was successful in its basic mission, namely to conduct the process of privatization. But the success came at a cost. The next subsection will address the main effects seen twelve years after the start of the process of the privatization.

\subsection{The effects of the privatizations}

Did the privatizations improve the economic environment and produce positive results in terms of governance, employment and social well-being in Kosovo? This section addresses that question and gives evidence that allows us to draw provisional conclusions on socio-economic development.

The academic discussion so far has been fixed predominantly at giving arguments in favor of privatization, based on the supremacy of private ownership and the positive effects of market economy. The interviewed Kosovo economists and IMF official also strongly supported privatization. They affirmed that for the Kosovo government, this was a method to "get rid of" public and socially owned enterprises in which one could not invest, to get the much needed finances and in 
the end to induce change and a better life (Ahmeti 2010, personal communication, 5 February 2010).

However, as we described in the previous subsection, the finances government received for the privatized companies were much lower than their real value. Furthermore, in society, the process was accompanied by important economic and social suffering. Unemployment is still exceptionally high, namely a $35.3 \%$ of the active population in 2014 (Trading Economics 2016). Youth unemployment (15-24) is around $60.2 \%$ (http://www.ks.undp.org/content/kosovo/en/home/countryinfo/). This issue represents a challenge for society as Kosovo's population is the youngest in Europe, with more than $50 \%$ of the population being between 15 and 30 years old, and each year between 30,000 and 50,000 students graduate from highereducation institutions. The labor market is unable to create jobs for such a high number of new entrants, and unemployment continues its rising trend (IMF 2013; KAS 2014a).

The third unintended outcome is that the trade balance is extremely unbalanced in favor of imports of about 2.2 billion Euros for 2014 (2.5 B€ concern the imports and $0.3 \mathrm{~B} €$ the exports (MTI 2015). More specific for the privatized companies is that around $30 \%$ thereof are now out of function/off the market (Mustafa et al. 2008) and an equal percentage of owners have rented out the real estate or workplace they previously bought. In other CEE countries, international investors expressed a great interest in buying themselves in, but in Kosovo international investors did not show a great interest in shares of the privatized companies. The reason most often mentioned is Kosovo's unstable political status, issues around ambiguous ownership and the lack of an institutional framework including a strong judicial system (Kullashi et al. 2005).

Privatization also did not reduce corruption. Corruption and inequalities have reached unprecedented levels. Data from the World Governance Indicators point out that Kosovo scores much worse than other European and Central Asian countries on indicators for good governance, such as voice and accountability, government effectiveness, regulatory quality, rule of law and the control of corruption. With regard to all six indicators for good governance, Kosovo belongs to the lower half of all countries in the world, and the situation has not improved between 2008 and 2014 (http://info.worldbank.org/governance/wgi/index.aspx\#home).

Although such statistics are not fully reliable, the indicators are supported by the managers of privatized enterprises. In 2008, $82 \%$ of them considered corruption to be widespread in Kosovo (Mustafa et al. 2008). The justice system is considered to be too weak, albeit strongly controlled by the UN until 2008 and then by the EU. The majority of Kosovo citizens also consider local judges to be corrupted and that claimants hardly had a chance to have their affairs be addressed properly. Consequently, trust in public institutions is low, resulting in turnouts at elections of less than $50 \%$ of the population. New populist parties have emerged, building their 
political program around the rejection of the views of the traditional parties and of the international mission. These are considered to be corrupt, untouchable and harmful to society.

Furthermore, there are many serious issues regarding the daily life of Kosovo citizens and basic public-service delivery, including healthcare, quality education and social security. The bad shape of all these policy areas have pushed a high number of them to migrate to Western Europe and seek for a better life (cf. Gerxhaliu, personal communication, 12 February 2010, Musliu, personal communication, 4 April 2015). Although these are general economic developments which cannot all be blamed on the process towards privatization, they do show that the dominant economic policy of privatization did not have any positive effects in this regard.

More specific effects of privatization are pointed out by Musliu (personal communication, 4 April 2015). In this communication, Musliu concluded that the privatization has been subject to an enormous mismanagement (bureaucratic decisions, political interferences, issues with property rights even after the companies were privatized etc.). This is a surprising assessment for a mission that wanted to create an independent agency. The management of KTA was appointed by and accountable to the SRSG (Ante 2010). Four members of the Board of KTA were members of the team of SRSG, acting out of the position of Deputy SRSGs (Knudsen 2010). This situation raises questions about the responsibility and accountability of the agency's leadership. In addition to a limited term of office, the leadership of the mission and agency benefited from total immunity. With the benefit of hindsight one can conclude that this enabled them to manage the process in a way favoring their own personal interest instead of the common interest. Although it has not been proven that UN agents were involved in corruption affairs or were aware of corruption affairs during the process, the process has been accompanied by suspicious affairs of corruption, abuse of information and power (Ahmeti 2010, personal communication, 5 February 2010). Peterson (2014) argues that:

Both the international community as well as domestic actors have used the process to further their own aims in the territory, preventing the potential of privatization to be used effectively to positively transform economic relationships (Peterson 2014, 135).

Next, if privatization was meant to end state monopolies, in fact it just transformed them into private monopolies. Privatization in Kosovo has helped the establishment of a few giant companies that have close ties with politicians and control large sectors of the economy (Gerxhaliu, personal communication, 12 February 2010). The assumption that privatization would bring an end to state monopolies, ensure competition and liberalize the market has not been realized in Kosovo. There is still no competitive market, but rather a market full of private monopolies controlled indirectly by representatives of the dominating political parties. 
Privatization also did not prevent inequalities and can even be said to have contributed to the concentration of wealth in the hands of small groups (cf. Starr 1988). In 2011, general poverty affected $29.7 \%$ of the population with $10.2 \%$ being in extreme poverty (KAS 2014b, http://www.ks.undp.org/content/kosovo/en/ home/countryinfo/). In 2010, the Japan International Cooperation Agency estimated that between 2002 and 2005 the Gini index increased from 0.27 to 0.30 , although specifying that the data is not fully reliable (JICA 2010). This is relatively high from a European perspective.

Our interviews with economists of the Macroeconomic department under the Prime Minister of Kosovo also show that they evaluate the process as "not totally successful", which is a diplomatic response. According to them the privatization was a policy to disengage the State and, more importantly, to avoid any further use of public and state-owned enterprises by politicians as political and campaign instruments. However, the privatized companies seem to be as strongly related to politicians and political parties as the public enterprises once were. The main difference is that because it concerns privatized companies, the institutional checks and balances occur even less.

\section{Conclusions}

This article assessed the effects of the privatization processes in Kosovo between 1999 and 2008, during which a UN mandate governed Kosovo (Lemay-Hébert and Murshed 2016).

The research question underlying this article reads: "What were the effects of the privatization processes in Kosovo in terms of governance, employment and social well-being?" The privatization in Kosovo between 1999 and 2008 can be seen as an extreme case, as strong institutions in the country were severely missing and the country was governed by a UN mandate.

The case study points out that the privatization processes did not bring about the positive effects expected from such a policy. Overall, it cannot but be concluded that privatization in Kosovo was an experience with only negative effects. Privatization did not ameliorate the employment rate in Kosovo. On the contrary, twelve years after the start of the privatization process, employment seems to have constantly decreased, and the U-shape tendencies with regard to employment, which some economists propagating privatization have predicted, have not been visible in Kosovo (i.e. after privatization, an important decrease of employment followed by a significant improvement).

The expected economic and social development, as argued by orthodox theories and the international administration that drove the process, has also not been achieved. Nowadays poverty affects one-third of Kosovo's population. Increasing inequalities are visible and continue to increase. Unemployment is extraordinarily 
high, and there are signs of self-enrichment of politicians and unfulfilled campaign promises that discourage citizens from participating in the democratic process. Trust in public institutions is consequently low.

It appears that the basic cause for the disappointing effects is the one-sided focus on privatization without first creating the needed conditions, institutions and legislative framework able to steer the process and have it accompanied with checks and balances. Instead, the process was mismanaged, conducted without clear objectives and planned without the needed checks and balances being in order.

In conclusion, this article argues that privatization processes are in need of a supportive socio-economic, political and institutional context and that the international privatization model implemented in Kosovo neglected the absent institutional context and the country's poor socio-economic and political situation. The lack of appropriate institutions, of a legislative framework and of a proper strategy are judged to be the main cause for the failure of the process of privatization engaged by the international administration of UNMIK in Kosovo.

If neo-liberal theories praise privatization in general for its positive effects on socio-economic developments, the reality in Kosovo does not confirm these expectations. Rather, major irregularities and a lacking strategy characterized the privatization processes, which therefore resulted in a deterioration of the lives of Kosovars (S. Musliu, personal communication, 4 April 2015). This outcome is supportive for the institutionalist approach to privatization. It results in the plea to international organizations to ensure that the institutional context in a country is adequate before one starts such far-reaching processes as the privatization of major state-owned companies.

\section{References}

Ante, A. 2010. State Building and Development: Two Sides of the Same Coin? Exploring the Case of Kosovo. Hamburg: Disserta.

Bayliss, K. 2005. Post-Conflict Privatisation: A Review of Developments in Serbia and Bosnia and Herzegovina. London: Overseas Development Institute.

Bel, G. and M. Warner. 2006. Local Privatization and Costs: A Review of Empirical Evidence. Paper presented at the Barcelona International Workshop on Local Government Reform: Privatization and Public-Private Collaboration, 12-13 June, in Barcelona, Spain.

Bozeman, B. 2007. Public Values and Public Interest: Counterbalancing Economic Individualism. Washington DC: Georgetown University Press.

Brossard, Y. and J. Vidal. 2001. Léclatement de la Yougoslavie de Tito. Québec: Les Presses de l'Université de Laval et L'Harmattan. 
Castellan, G. 1994. Le monde des Balkans. Paris: Editions Vuibert.

Dan, S. and C. Pollitt. 2015. "NPM Can Work: An Optimistic Review of the Impact of New Public Management Reforms in Central and Eastern Europe." Public Management Review 17(9), 1305-1332.

Demekas, D., J. Herderschee and D. Jacobs. 2002. Kosovo: Institutions and Policies for Reconstruction and Growth. Washington, DC: International Monetary Fund.

Dobruna, K. 2007. Investments in Privatization: Wave 1-22. Vienna: ECIKS.

Drechsler, W. and T. Randma-Liiv. 2015. The New Public Management Then and Now: Lessons from the Transition in Central and Eastern Europe. In J. Nemec and M. S. de Vries 2015, 33-49.

European Commission and the World Bank. 1999. Toward Stability and Prosperity: A Program for Reconstruction and Recovery in Kosovo. 3 November, Pristina, Available at http://ec.europa.eu/enlargement/archives/seerecon/kosovo/documents/kosovo_toward_stability_and_prosperity_1999.pdf (last accessed 15 September 2015).

Garde, P. 2000. Vie et mort de la Yougoslavie. Paris: Editions Fayard.

Hanley, S. L. and J. Dawson. 2016. "East Central Europe: The Fading Mirage of the 'Liberal Consensus"' Journal of Democracy 27(1), 20-34.

Harvylyshyn, O. and D. Mc Gettigan. 1999. "Privatization in Transition Countries: Lessons of the First Decade.” Washington DC: IMF Economic Issues No 18.

IMF. 2013. Country Report No. 222. Washington DC: IMF Publication Services.

Jensen, M. and W. Meckling. 1976. "A Theory of the Firm: Governance, Residual Claims and Organizational Forms." Journal of Financial Economics 3(4), 305-360.

JICA. 2010. Republic of Kosovo Study for Poverty Profile in European Region, Available at http://www.jica.go.jp/activities/issues/poverty/profile/ku57pq00001mop83-att/kos_03.pdf (last accessed 16 May 2015).

KAS. 2014a. Results of the Kosovo 2013 Labour Force Survey. Prishtina: Kosovo Agency of Statistics.

KAS. 2014b. Statistical Yearbook of the Republic of Kosovo. Prishtina: Kosovo Agency of Statistics.

Knudsen, R. 2010. Privatization in Kosovo: The International Project 1998-2008. Oslo: Norwegian Institute of International Affairs.

Komisar, L. 2011. Interview with Joseph Stiglitz. Global Policy Forum. Available at https://www.globalpolicy.org/social-and-economic-policy/the-three-sistersand-o (last accessed 15 May 2015). 
Kornai, J. 1999. "Du socialisme au capitalisme: La signification du 'changement de système."' In B. Chavance et al (ed.). Capitalisme et socialisme en perspective. Evolution et transformation ds systèmes économiques. Paris : Ed. La Découverte, $317-347$.

Kornai, J. 1986. “The Soft Budget Constraint.” Kyklos 39-1986, Fasc 1. 3-30.

Kosovo Foundation for Open Society. 2012. "Environmental Mosaic: 4 Case Studies Challenge the Governance." Forum 2015, Prishtina.

KTA. Undated document. Rules of Tender for the Spin-Off Privatisation of [Newco L.L.C./Tender Number]. Available at http://kta-kosovo.org/html/index.php? module $=$ htmlpages\&func $=$ display\&pid $=6$ (last accessed 14 April 2016).

Kullashi, M. et al. 2005. "Pourquoi l'indépendance pour le Kosovo?" Forum 2015, Prishtina.

Labaronne, D. 2001. "Privatisation et croissance dans les pays de lest." Économie internationale 2(86), 77-98.

Labaronne, D. 1999. Les privatisations à l'Est. Caen: Editions Management et Société.

Laffont, J-J. and J. Tirole. 1991. "Privatization and Incentives." Journal of Law, Economics and Organization 7, 84-105.

Lemay-Hébert, N. and S. M. Murshed. 2016. Rentier Statebuilding in a Post-Conflict Economy: The Case of Kosovo. Development and Change. 47:517-541.

Lipton, D. and J. Sachs. 1990. "Privatization in Eastern Europe: The case of Poland." Brookings Papers on Economic Activity 2, 293-341.

Malcolm, N. 1998. Kosovo: A Short History. London: Macmillan.

MTI, Ministry of Trade and Industry. 2015. Shkëmbimet tregtare 2014. Available at http://www.mti-ks.org/repository/docs/shkembimet_tregtare_2014_155559.pdf (last accessed 12 October 2015).

Mustafa, M. et al. 2008. "Privatization and Post-Privatization in Kosovo: Glass Half Empty of Half Full?” Riinvest Institute Research Report. Forum 2015, Prishtina.

Nemec, J. and M. S. de Vries (eds). 2015. Implementation of New Public Management Tools. Brussels: Bruylant.

North, D. 2014. Prize Lecture: Economic Performance through Time. Nobelprize.org. Nobel Media AB 2014. Available at http://www.nobelprize.org/nobel_prizes/ economic-sciences/laureates/1993/north-lecture.html (last accessed 25 May 2015).

North, D. 1991. Institutions, Institutional Change and Economic Performance. Cambridge: Cambridge University Press. 
OSCE. 2008. Judicial Review of Kosovo Trust Agency Matters by the Special Chamber of the Supreme Court of Kosovo. Prishtina: OSCE.

PAK. 2015. Annual Report 2014 of The Privatisation Agency Of Kosovo For The Assembly Of The Republic Of Kosovo. Prishtina: Privatisation Agency of Kosovo.

PAK. 2009. Work Report: August 2008-August 2009. Prishtina: Privatisation Agency of Kosovo.

Pavlovic, M. 2013. "Yugoslavia - the Constitution of 1974 and some Political Results." TransConflict. Available at http://www.transconflict.com/2013/04/ yugoslavia-the-constitution-of-1974-and-some-political-results-19/ (last accessed 20 December 2015).

Peterson, J. H. 2014. Building a Peace Economy? Liberal Peacebuilding and the Development-Security Industry. Manchester: Manchester University Press.

Roland, G. 2008. "Private and Public Ownership in Economic Theory.” In G. Roland (ed.). Privatization: Successes and Failures. New York: Columbia University Press, 9-31.

Savas, E. S. 2000. "Privatization and the New Public Management." Fordham Urban Law Journal 28(5), article 8.

Starr, P. 1988. “The Meaning of Privatization.” Yale Law \& Policy Review 6(1), 6-41.

Stiglitz, J. E. 2008. "Foreword” in G. Roland (ed.). Privatization: Successes and Failures. New York: Columbia University Press.

Tirole, J. 1991. "Privatization in Eastern Europe: Incentives and the Economics of Transition.” NBER Macroeconomics 6, 221-268.

Top-Channel. 2015. PTK, nё Arbitrazh; Mustafa: Po frikësohen investitorët. Available at http://Top-Channel.Tv/Lajme/Artikull.Php?Id=309932 (last accessed 15 December 2015).

Trading Economics. 2016. Kosovo-Indicateurs économiques. Available at http:// fr.tradingeconomics.com/kosovo/indicators (last accessed 15 January 2016).

UNMIK. 2002. Regulation No. 2002/12 on the establishment of the Kosovo Trust Agency. Available at http://www.unmikonline.org/regulations/2002/RE2002_12. pdf (last accessed 4 April 2015).

World Bank. 2001a. Kosovo, Federal Republic of Yugoslavia - Kosovo Economic Assistance Project. Washington, DC: World Bank. Available at http://documents. worldbank.org/curated/en/2001/06/1490211/kosovo-federal-republic-yugoslavia-kosovo-economic-assistance-project (last accessed 8 September 2015). 
World Bank. 2001b. Kosovo: Economic and Social Reforms for Peace and Reconciliation. World Bank technical paper 509. Washington, DC: The World Bank. Available at http://documents.worldbank.org/curated/en/2001/05/1620973/ kosovo-economic-social-reforms-peace-reconciliation (last accessed 8 September 2015).

Wright, M. 1993. "A Critique of the Public Choice Theory Case for Privatization: Rhetoric and Reality." Ottawa Law Review 25(1), 1-38. 